\title{
Population dynamics of willow coppice systems and their implications for management of short-rotation forests
}

\author{
by Eva Willebrand and Theo Verwijst
}

\begin{abstract}
Spacing, length of rotation and clonal composition of Salix coppice systems determine the degree of within-stand competition and thereby the dynamics of the populations. Three general effects of competition are identified and their dependence on planting design and management is illustrated. (1) The dependence of yield on initial planting density disappears at higher densities and becomes weaker at low densities in later rotations. (2) The development of a competitive hierarchy between stools is reflected by a temporal increase of skewness and relative variation in weight frequency distributions. (3) Mortality of stools due to self-thinning is enhanced by high planting density and longer cutting cycles. Furthermore, the relative performance of clones in a mixture cannot be predicted from their performance in pure stands.
\end{abstract}

Key words: Biomass production, Clone mixture, Competition, Rotation length, Salix, Self-thinning, Spacing, Willow coppice
L'espacement, la durée de la révolution et la composition des clones utilisés selon les méthodes de taillis chez les saules déterminent le degré de compétition au sein du peuplement et en conséquence la dynamique des populations. Trois effets généraux issus de la compétition ont été identifiés et leurs conséquences sur le schéma de plantation et sur l'aménagement sont abordées. (1) La conséquence sur le rendement de la densité initiale de plantation disparaît sous des densités supérieures et devient moins importante sous des densités inférieures vers la fin de la révolution. (2) Le développement d'une hiérarchie compétitive entre les rejets se reflète par un accroissement dans le temps de l'inclinaison de la tige et par la variation relative des distributions des fréquences de poids. (3) La mortalité des rejets par suite d'éclaircie naturelle est accrue par la densité élevée de plantation et par des cycles plus longs de coupe. De plus, la performance relative des clones dans une plantation mélangée ne peut être prédite à partir de leur performance en peuplement pur.

Mots clés: Production de biomasse, mélange de clones, compétition, durée de la révolution, Salix, éclaircie naturelle, espacement, taillis de saule.

the degree of between-stool variation, reduce the number of stools, thereby diminishing future sustainability of the system. Spacing and length of the cutting cycle may be balanced to avoid stool thinning.

In this study, we illustrate features of the population dynamics of three coppice trials with Salix. The first trial is a production test under optimal nutrient and irrigation conditions; the second trial is a spacing-rotation test for one clone. In the last trial, a comparison is made between the performance of clones in mixed and pure stands. Eckersten et al 1987), thereby excluding the possibility to detect plant to plant interactions. Some recent studies with a population dynamical approach showed that such interactions may be of importance for stool survival (Verwijst 1990) and stand structuring (Verwijst 1991a).

In ecological literature, three general effects of competition have been described, which can be expected to influence decisions on planting design and stand management of coppice systems. Firstly, the "law of constant final yield' (Kira et al. 1953), which states that total yield, with increasing planting density, becomes independent of planting density, may be used to determine the number of cuttings to be planted. Secondly, a competitive hierarchy (Weiner and Thomas 1986) becomes established, showing dominant and suppressed individuals. This hierarchy development is reflected in changing size and weight frequency distributions (Koyama and Kira 1956; Ford and Newbould 1970). Timing of harvest may be based on the hierarchical status of a stand, to avoid a decrease in stool viability. Finally, self-thinning (Yoda et al. 1963) will reduce the number of shoots per stool and, depending on

The Swedish University of Agricultural Sciences, Department of Ecology and Environmental Research, Section of Intensive Short-Rotation Forestry, Box 7072, 75007 Uppsala, Sweden.

\section{Material and Methods \\ Site Descriptions}

The first trial was planted in 1984 at Ultuna, Uppsala $\left(59^{\circ} 49^{\prime} \mathrm{N}, 17^{\circ} 40^{\prime} \mathrm{E}, 5 \mathrm{~m}\right.$ asl), and consisted of a pure $\mathrm{m}^{2}$, on a Vertic cambisol with $\mathrm{pH}$ values around 7.3 and a good nutrient status (Olsson and Samils 1984). Irrigation and fertilization were supplied with a drip irrigation system according to theories developed by Ingestad et al. (1981) and Ingestad (1987). During winter 1986-1987, the stand was coppiced and the data used in this study were collected during its second cutting cycle (1987-1990).

The second trial was laid out at the Malmön experimental field station, near to Köping $\left(59^{\circ} 29^{\prime} \mathrm{N}, 16^{\circ} 04^{\prime} \mathrm{E}, 5 \mathrm{~m}\right.$ asl) in 1984 and was designed to assess both different spacing and rotation lengths of clone 77-683. The soil is a water sediment deposited in a former lake. The top soil consists of clay (50\%), humus (3-6\%) and silt (44-47\%) with a CEC of $24 \mathrm{meq} / 100 \mathrm{~g}$ dry soil. A top soil $\mathrm{pH}$ of 5.5 to 6.2 was reached after liming. The test site was fertilized with $100 \mathrm{~kg} \mathrm{~N}$ per year and no irrigation was applied. Weed control was maintained chemically during two occastand of 2.7 ha with clone $77-683$ at a spacing of $0.7 \times 0.7$ 
sions, and during later years mechanical weed control was applied. After the establishment season, shoots were cut back to promote more shoots per stool (Sirén et al. 1987). The trial consisted of $10 \times 10 \mathrm{~m}^{2}$ plots and was planted in 1984 in 4 sections, one for each rotation period (1 - 4 year cycles). Each section included four blocks with four square spacings $(0.5,0.6,0.7$ and $1.0 \mathrm{~m})$ in each block.

The third trial, also situated at the Malmön station and subjected to the same soil preparation, weeding and fertilization treatments as trial 2, consisted of a 5-year cutting cycle with three different designs, all with a spacing of $1 \times 1 \mathrm{~m}^{2}$. The first design contained 4 replicates of pure stands $\left(10 \times 10 \mathrm{~m}^{2}\right.$ each) of the 10 clones involved (Table 1$)$; the second included 4 replicates of 10 randomly ordered rows, each row containing one of the 10 clones, and the third contained 40 replicated mixtures of 10 plants, all clones being present in each replicate, but planted in random order.

\section{Sampling and Analysis}

In trial 1, the size of all living shoots of 228 stools was measured during three consecutive winters in the second cutting cycle. Biomass production of shoots and stools in this trial was estimated non-destructively (Verwijst 1991b). In trial 2, fresh weight of 40 living plants per spacing (10 plants per block) was measured during each harvest. For each harvest in trial 3, above ground fresh weight was determined on 40 living plants per clone in the pure stands (10 plants per block), 40 living plants per clone in the row design and on 20 living plants per clone in the single-tree design ( 20 out of the 40 replicates). In all samplings, plants were chosen randomly and border effects were avoided where possible by exclusion of two or three outer rows (Zavitkovski 1981). Biomass estimation in trials 2 and 3 was carried out by conversion of fresh weight values into dry weight values ( 4 days at $105^{\circ} \mathrm{C}$ ) on the basis of dry weight-fresh weight ratios obtained from 5 samples for each of the clones, spacing and rotation cycle combinations. Weight per area values were calculated on basis of sample weights, initial planting density and stool survival at each harvest time. Damage caused by insects and leaf rust was assessed in all trials each year during early autumn and browsing damage due to hare and roe deer was assessed at harvest time. All harvests were performed during December-March.

Yield $(Y)$ and density $(D)$ were examined with the Mitscherlich function (Meyer 1940):

$$
Y=a\left(1-b e^{-\mathrm{cD}}\right)
$$

Parameter $\mathrm{a}$ is the asymptote, $\mathrm{b}$ is a measure of the starting size of the system and $\mathrm{c}$ is a rate constant (Hunt 1982).

\section{Results}

The weight frequency distribution of shoots in a pure stand of clone 77-683 was positively skewed after the first growing season in the second cutting cycle (Figure 1). One year later, both the coefficient of variation (CV) and skewness (SK) had increased further in this population while some shoot mortality (13\%) had commenced. After the third season, both the CV and SK had decreased again to attain values below the ones obtained after one growing season. Cumulative shoot mortality had reached $83 \%$ after three seasons. The average number of shoots per stool
Table 1. The following clones were used in the trials described: The SRF-clone number is according to Ager et al. (1986).

\begin{tabular}{ll}
\hline SRF-clone number & SPECIES \\
\hline 77077 & Salix schwerinii \\
77082 & Salix, mixture \\
77683 & Salix viminalis \\
81090 & Salix dasyclados \\
78003 & Salix viminalis \\
78021 & Salix viminalis \\
78090 & Salix viminalis \\
78183 & Salix viminalis \\
78195 & Salix viminalis \\
78196 & Salix dasyclados \\
\hline
\end{tabular}

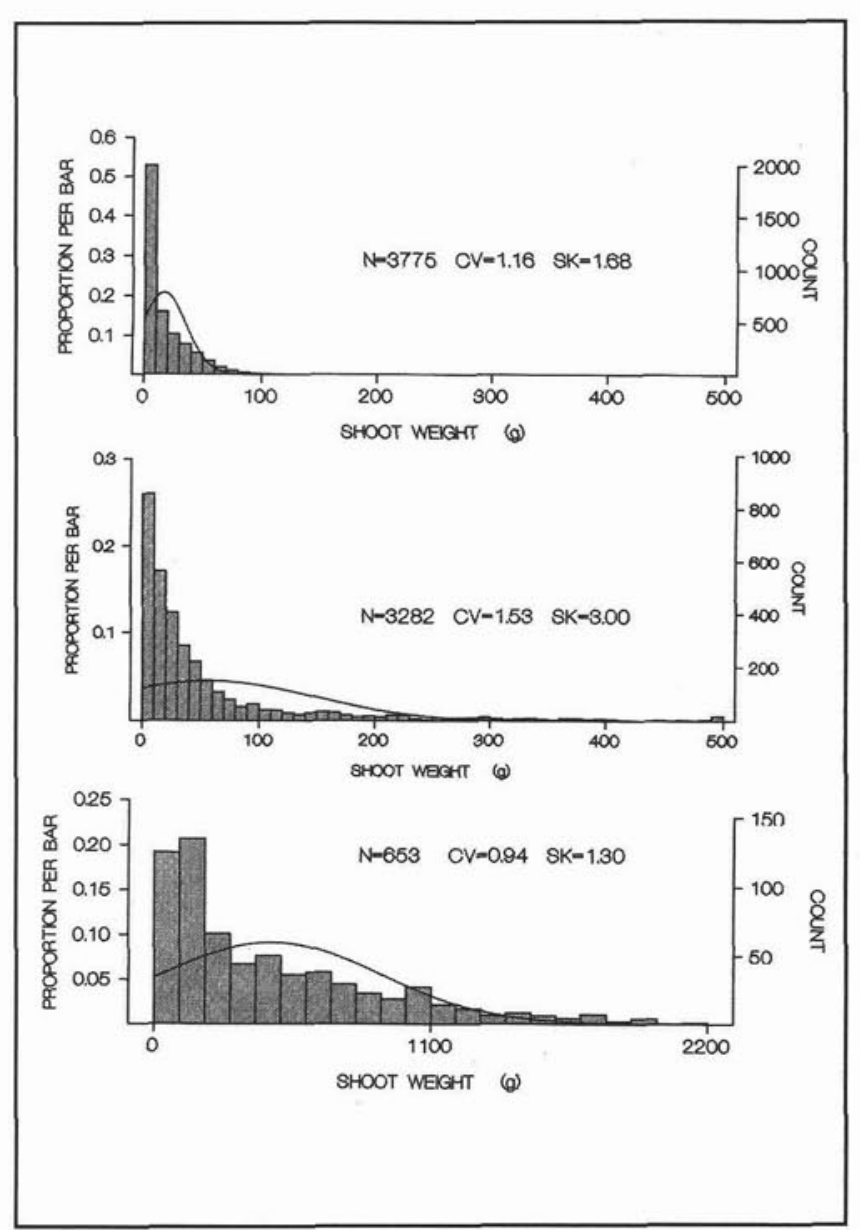

Figure 1. Dry weight frequency distributions of shoots after 1, 2 , and 3 growing seasons in the second rotation period of a Salix viminalis coppice system. Weight classes of $10 \mathrm{~g}$ for season 1 and 2 and of $100 \mathrm{~g}$ for season 3 were used. Number of living shoots $(\mathrm{N})$, the coefficient of variation $(\mathrm{CV})$ and skewness (SK) are indicated and a normal distribution is shown for comparison.

dropped from 16.6 after the first season to 3.9 after three seasons.

The course of the CV and SK through time for the stool population differs from those observed in the shoot population. The $\mathrm{CV}$ increased from 0.66 to 1.10 during three seasons, while SK increased from 0.85 to 1.80 (Figure 2). When comparing the stool population with the shoot population, the former lagged behind in the development of a competitive hierarchy. Cumulative stool mortality 

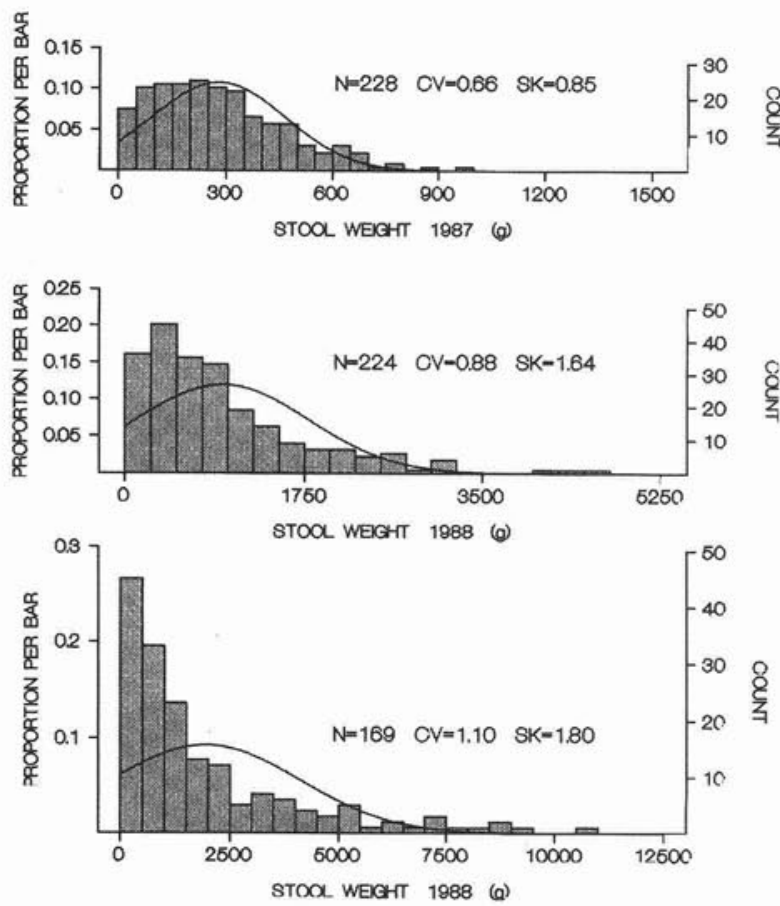

Figure 2. Dry weight frequency distributions of stools after 1, 2, and 3 growing seasons in the second rotation period of a Salix viminalis coppice system. Weight classes of 50, 250 and $500 \mathrm{~g}$ were used for season 1,2, and 3 respectively. Number of living stools (N), the coefficient of variation (CV) and skewness (SK) are indicated and a normal distribution is shown for comparison.

increased from 2 to $26 \%$ during the third season.

A plot of yield against planting density for 3 cutting cycles (2, 3 and 4 years), showed that longer cycles gained a higher total yield (Figure 3 ). The 2 and 3 year cutting cycles displayed higher yields at the second harvest compared to the first one. The 2-year cycle had about the same total yield during harvest 2 and 3, and its mean annual increment (MAI) was equal to the MAI obtained at the first harvest of the 3 year cutting cycle (Table 2). Total yields did not differ for the first harvests of cutting cycle 3 and 4 , which means that the 3 year cycle displayed the highest MAI.

The maximum standing biomass per area which can be achieved by a predefined number of stools per area theoretically is constrained by a negative exponential self-thinning curve (Westoby 1984). A thinning curve, derived independently from the first trial, was transformed on a double logarithmic scale into a self-thinning line, and plotted together with mass-density data for consecutive harvests from 1 to 4 year cutting cycles (Figure 4). Generally, second and further harvests at close spacings were situated nearer to the thinning line than wider spacings at the first harvests. The different spacings converged in later harvests with respect to yield and number of shoots per area. Second harvests of one-year cutting cycles were located around the self-thinning line, but their third harvests did not reach the self-thinning line, irrespective of spacing,

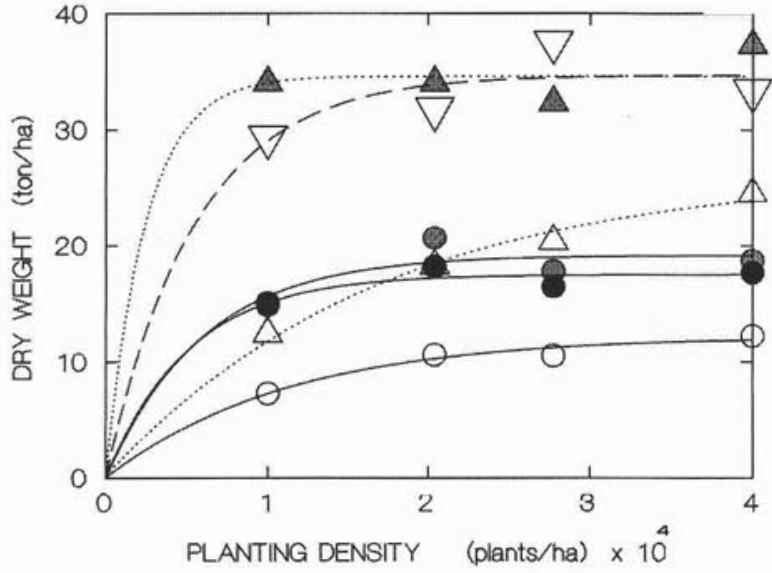

Figure 3. Standing dry weight-density relations for $2(-, 0)$, $3(----, \Delta)$ and 4 -year rotation periods $(--, \nabla)$. Open symbols indicate a first harvest, grey symbols a second harvest and black symbols a third harvest. Data were fitted with the Mitscherlich function.

Table 2. Final yield for different cutting cycle lengths and harvest occasions. The asymtotic total yield (oven-dry weight) is calculated on basis of the Mitscherlich equations.

\begin{tabular}{lllll}
\hline $\begin{array}{l}\text { Length of } \\
\text { cutting } \\
\text { cycle } \\
\text { (year) }\end{array}$ & $\begin{array}{l}\text { Harvest } \\
\text { occasion }\end{array}$ & $\begin{array}{l}\text { Asymtotic } \\
\text { total } \\
\text { yield } \\
\text { (ton/ha) }\end{array}$ & $\begin{array}{l}\text { Asymtotic } \\
\text { standard } \\
\text { error } \\
\text { (ton/ha) }\end{array}$ & $\begin{array}{l}\text { Mean } \\
\text { annual } \\
\text { increment }^{\mathbf{1}} \\
\text { (ton/ha/yr) }\end{array}$ \\
\hline 2 & 1 & 12.2 & 0.7 & 6.1 \\
2 & 2 & 19.2 & 1.2 & 9.6 \\
2 & 3 & 17.5 & 0.7 & 8.8 \\
3 & 1 & 26.6 & 2.0 & 8.9 \\
3 & 2 & 34.5 & 1.5 & 11.5 \\
4 & 1 & 34.6 & 1.9 & 8.7 \\
\hline
\end{tabular}

${ }^{1}$ Calculated as: total yield/cutting cycle length.

implying that another process than density-dependent mortality was involved.

Stool survival after 8 years (Figure 5) at the Malmön station was primarily a function of initial planting density. The widest spacing lost on average $15 \%$ of its stools during this period, while the closest spacing lost on average $45 \%$. However, rotation length also affected stool mortality, mortality being slightly higher in the longer rotations within each spacing. Within each spacing, this negative effect of cutting cycle length became stronger at closer spacings.

A comparison of clone performance in pure stands with mixtures planted randomly and in mono-clonal rows showed that the latter designs deviated in the same way from the pure stands (Figure 6). Two clones performed equally low in all designs, because their performance was not related to within stand competition but to external factors: Clone 78090 was heavily browsed by hares and clone 78196 suffered from leaf rust, while the other clones remained unaffected by these agents. The ranking which was obtained on basis of the performance of pure stands did not correlate with the ranking of the other designs. The performance of clones in mixtures cannot be predicted 


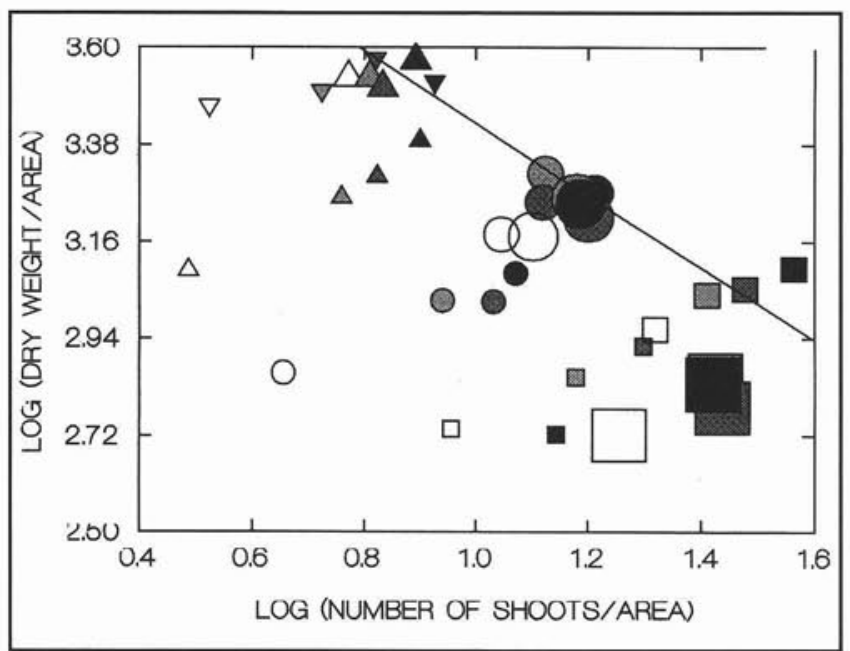

Figure 4. The relation between dry weight $\left(\mathrm{g} \mathrm{m}^{-2}\right)$ and number of shoots $\left(\mathrm{m}^{-2}\right)$ for cutting cycle lengths of $1(\square)$, two $(\mathrm{o})$, three $(\Delta)$ and four years $(\nabla)$ at different spacings. Symbol size indicates harvest occasion (small $=$ first harvest) and shading indicates spacing: $1.00 \times 10^{4}, 2.04 \times 10^{4}, 2.77 \times 10^{4}$ and $4.00 \times 10^{4}$ plants per hectare are indicated by white, light grey, dark grey and black shading, respectively. A self-thinning line with a slope of -0.821 , derived from an independent stand, is used to assess the thinning status of the plots: Dense spacings and later harvests were nearer to the self-thinning line than wide spacings and first harvests.

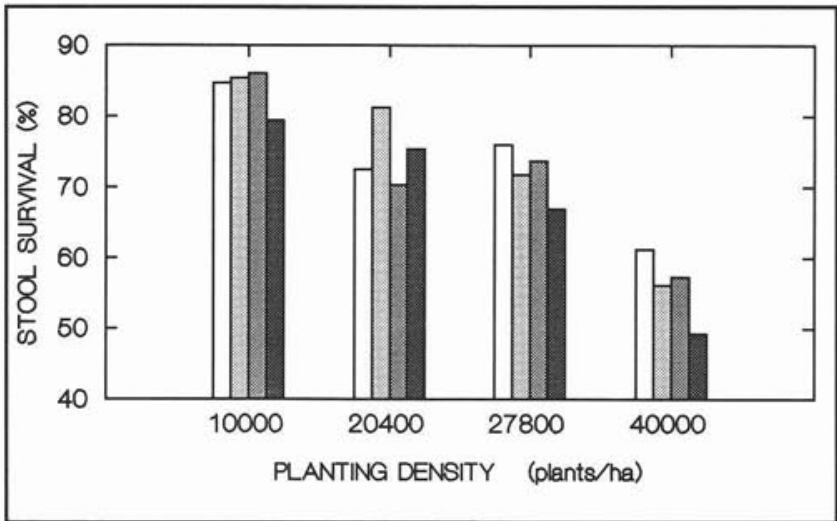

Figure 5. Stool survival after 8 years. The degree of shading indicates the length of the cutting cycle (white $=1$ year, black $=4$ years).

from their relative performance in pure stands.

\section{Discussion}

Before competition leads to density-dependent mortality, it changes the size and weight distributions within populations towards an increasing inequality between dominant and suppressed individuals. Assuming a normal distribution of initial weights (Koyama and Kira 1956; Black 1957) and a variance in initially exponential growth rates (Hunt 1978), a population will acquire a positively skewed weight distribution, even when no interference occurs. Competition amplifies the relative weight differences within a population (Begon 1984) by slowing down the growth rates of the smallest individuals, while growth rates of large individuals are less affected. The observed changes in

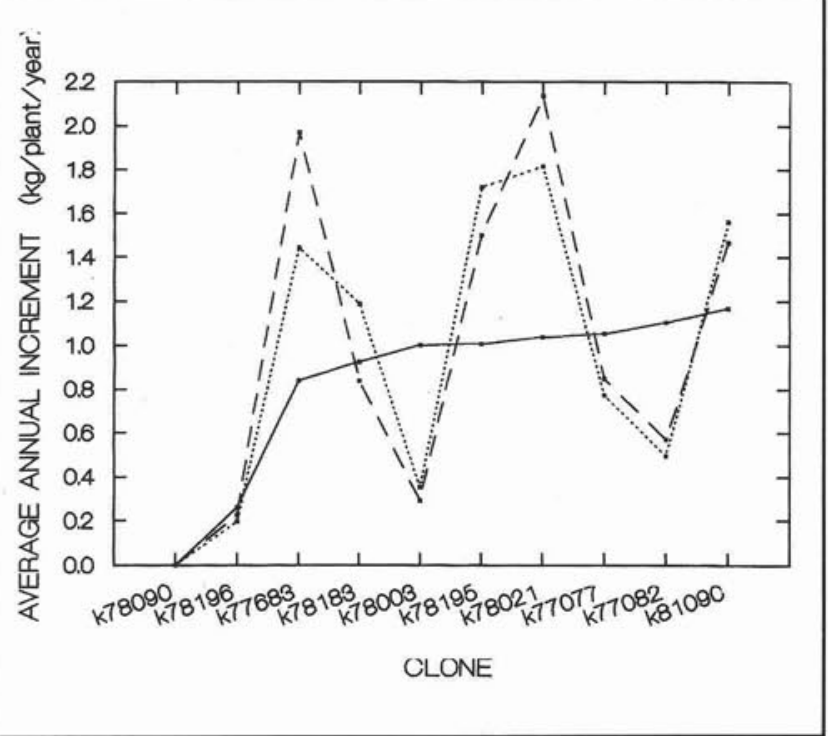

Figure 6. The average annual dry weight production of 10 clones during a five-year cutting cycle in pure stands (-), in randomly ordered rows, each containing one clone $(--)$, and in random mixtures, containing all clones (----).

weight distributions are consistent with results reported by Koyama and Kira (1956), Ford and Newbould (1970) and Mohler et al. (1978). The reported decrease in CV and SK, after an initial increase, can be attributed to self-thinning, which removes the left tails of the distributions (Weiner and Thomas 1986).

The observation of $80 \%$ shoot mortality and a $26 \%$ stool mortality in a pure stand after three years in a second rotation leads to the question about the relation between these mortality percentages. Shoot and stool mortality are not necessarily related. A certain variation in shoot weight can be divided equally among stools, to give a low variation in stool weight, or in such a way that the variation within stools is low but between stools becomes high. When the same number of shoots is removed due to self-thinning, the first stand maintains all its stools, while the latter will suffer from stool mortality.

The spacing rotation trial showed clearly the so-called yield-density effect, and also that the dependence of yield on plant spacing diminished in later rotations. Furthermore, the final yield of second harvests increased (Table 2) compared to the first harvests. These results are in accordance with studies on Salix by McElroy and Dawson (1985) and with reports from other coppice systems, e.g. with Platanus occidentalis (Wittwer et al. 1977) and Populus trichocarpa (Heilman and Peabody 1981). When fitting a Mitscherlich function through yield density data, the assumption is made that a constant final yield can be obtained. Willebrand et al. (1992) showed that there is solid ground for such an assumption, but not when applied to cutting cycles of 1 year for clone 77-683 under Swedish conditions. They noticed that short vegetation periods and a high cutting frequency caused such a system to collapse after about 5 years. We conclude that $2 \times 10^{4}$ cuttings per hectare is sufficient for a 2-year rotation cycle to reach its maximum yield already at the second harvest, and that about $10^{4}$ cuttings is sufficient in longer cutting cycles.

The above mentioned collapse of a one-year cycle is 
illustrated in Figure 4, where the last harvests of the oneyear cutting cycle had retreated from the thinning line, indicating that factors other than density dependent mortality lowered the production. The slope of the self-thinning line $(-0.821)$, used as a reference for the spacing rotation experiment, was derived from trial 1. The concept of one self-thinning line for different site conditions is controversial (Zeide 1985; Weller 1987; Hynynen 1993). However, the observed slope coincides well with an average slope value for shade tolerant species (Weller 1987) and is indicative for the thinning status of the compared points. The four-year cutting cycles were in a thinning phase during the last year of the first cycle, and the shorter cycles reached a thinning phase soon after the first harvest.

Willebrand et al. (1992) concluded that clone mixtures in 1 to 4 year cutting cycles performed better than pure stands because successful clones in mixtures could fill out gaps left by individuals which suffered from other impacts than competition. However, competition between clones in a mixture may lead to extinction of the clones which in an early phase become the suppressed ones in a competitive hierarchy (Verwijst 1993). No difference in overall performance was found between pure and mixed stands with 5 year cutting cycles, probably due to the fact that gaps have been filled out within a 5-year period. The large differences between the performances of individual clones in a mixture cannot be explained at this stage. A possible explanation may be found in the early growth rates of the clones. In a mixture, a "slow starter' may become suppressed in an early phase by clones which have lower inherent growth rates in a later phase.

In conclusion, spacing, rotation length and clonal composition of willow coppice systems need to be balanced to obtain a sustainable production, and suitable combinations of such cultivation measures may be deduced from the population dynamical performance of different stands. One year rotation cycles may be seriously constrained by the climate, and a bad year can cause the system to collapse. Three- and four year rotation cycles gave the best results, and could be run successfully at relatively wide spacings of $10^{4}$ cuttings.ha ${ }^{-1}$. More research, however, is needed to understand the within-stand processes which govern the performance of balanced clone mixtures.

\section{Acknowledgements}

We thank Prof. Lars Christersson for his constructive comments on the manuscript. The study was financially supported by the Swedish National Board for Industrial and Technical Development.

\section{References}

Ager, A., A. Rönnberg-Wästljung, J. Thorsén and G. Sirén. 1986. Genetic improvement of willows for energy forestry in Sweden. Swed. Univ. Agric. Sci., Sect. of Energy Forestry. Report 43.47 p.

Black, J.N. 1957. The early vegetative growth of three strains of subterranean clover (Trifolium subterraneum L.) in relation to size of seed. Australian Journal of Agricultural Research 8: 1-14.

Begon, M. 1984. Density and individual fittness: asymmetric competition. In: Shorrocks, B. (ed.). Evolutionary ecology. p175194. Blackwell. Oxford.

Eckersten, H. 1985. Comparison of two energy forest growth models based on photosyntesis and nitrogen productivity. Agric.
For. Meteorol. 34: 301-314.

Eckersten, H. 1986. Simulated willow growth and transpiration: the effect of high and low resolution weather data. Agric. For. Meteorol. 38: 289-306.

Eckersten, H., A. Lindroth and L.O. Nilsson. 1987. Willow production related to climatic variations in southern Sweden. Scand. J. For. Res. 2: 99-110.

Ford, E.D. and P.J. Newbould. 1970. Stand structure and dry weight production through the sweet chestnut (Castanea sativa Mill.) coppice cycle. J. Ecol. 58: 275-296.

Heilman, P. and D.V. Peaboby. 1981. Effect of harvest cycle and spacing on productivity of black cottonwood on intensive culture. Canadian Journal of Forest Research 11: 118-123.

Hunt, R. 1978. Plant growth analysis. Studies in biology No. 96. Edward Arnold, London.

Hunt, R. 1982. Plant growth curves. Edward Arnold, London.

Hynynen, J. 1993. Self-thinning models for even-aged stands of Pinus sylvestris, Picea abies and Betula pendula. Scandinavian Journal of Forest Research 8: 326-336.

Ingestad, T. 1987. New concepts on stand fertility and plant nutrition as illustrated by research on forest trees and stands. Geoderma 40: 237-252.

Ingestad, T., A. Aronsson and G.I. Ågren. 1981. Nutrient flux density model of mineral nutrition in conifer ecosystems. Stud. For. Suec. 160: 61-71.

Kira, T., H. Ogawa and K. Shinozaki. 1953. Intraspecific competition among higher plants. 1. Competition-density-yield interrelationships in regularly dispersed populations. J. Inst. Polytech. Osaka Cy. Univ. D. 4, 1-16.

Koyama, H. and T. Kira. 1956. Intraspecific competition among higher plants. 8. Frequency distribution of individual plant weight as affected by the interaction between plants. J. Inst. Polytech. Osaka Cy Univ. Ser. D. 7: 73-94.

McElroy, G. H. and W. M. Dawson. 1985. Biomass from short rotation coppice in Northern Ireland. In: Energy from biomass. 3th E.C. Conference (eds. Palz, W., Coombs, J., and Hall, D.O.). pp 264-268. Elsevier Applied Science Publishers, London.

Meyer, H.A. 1940. A mathematical expression for height curves. Journal of Forestry 38: 415-420.

Mohler, C.L., P.L. Marks and D.G. Sprugel. 1978. Stand structure and allometry of trees during self-thinning of pure stands. J. Ecol. 66: 599-614.

Nilsson, L.O. and H. Eckersten. 1983. Willow production as a function of radiation and temperature. Agric. Meteorol. 30: 4957.

Olsson, M.T. and B. Samils. 1984. Site characterisation at energy forest production. Department of Forest Soils, Swedish University of Agricultural Science, Uppsala. Rep. No. 48.

Sirén, G. 1983. Energiskogsodling. Nämnden för energiproduktionsforskning, Stockholm.

Sirén, G., L. Sennerby-Forsse and S. Ledin. 1987. Energy plantations - short rotation forestry in Sweden. In: Biomass. (Hall, D.E. and Overend, R.P., eds). pp. 119-143. John Wiley and Sons, U.K.

Verwijst, T. 1990. Clonal differences in the structure of a mixed stand of Salix viminalis in response to Melampsora and frost. Canadian Journal of Forest Research 20: 602-605.

Verwijst, T. 1991a. Shoot mortality and dynamics of live and dead biomass in a stand of Salix viminalis. Biomass and Bioenergy 1: 35-39.

Verwijst, T. 1991b. Logarithmic transformations in biomass estimation procedures: Violation of the linearity assumption in regression analysis. Biomass and Bioenergy 1: 175-180.

Verwijst, T. 1992. Energie uit biomassa in Zweden: Tijdelijke bestandschade en produktiehandhaving in wilgenbossen met korte omloopstijd. In: Het perspectief van zonne-energie. 3de nationale zonne-energie conferentie 1991. pp. 361-363. 
Verwijst, T. 1993. Influence of the pathogen Melampsora epitea on intraspecific competition in a mixture of Salix viminalis clones. Journal of Vegetation Science 4: 717-722.

Weiner, J. and S.C. Thomas. 1986. Size variability and competition in plant monocultures. Oikos 47: 211-222.

Weller, D.E. 1987. A revaluation of the $-3 / 2$ power rule of plant self-thinning. Ecological Monographs 57: 23-43.

Westoby, M. 1984. The self-thinning rule. Advances in ecological research 14: 167-226.

Willebrand, E., S. Ledin, and T. Verwijst. 1993. Willow coppice systems in short rotation forestry: Effects of plant spacing, rotation length and clonal composition on biomass production. Biomass and Bioenergy 4: 323-331.
Wittwer, R.F., R.H. King, J.M. Clayton, and O.W. Hinton. 1977. Biomass yield of short rotation American sycamore as influenced by site, fertilisers, spacing and rotation age. Southern Journal of Applied Forestry 77-8-163. pp. 15-19.

Yoda, K., T. Kira., M. Ogawa and K. Hozumi. 1963. Intraspecific competition among higher plants. 4. Self-thinning in overcrowded pure stands under cultivated and natural conditions. J. Biol. Osaka Cy Univ. 14: 107-129.

Zavitkovski, J. 1981. Small plots with unplanted plot border can distort data in biomass production studies. Can. J. Forest Res. 11: 9-12.

Zeide, B. 1985. Tolerance and self-tolerance of trees. Forest Ecology and Management 13: 149-166.

\section{Change of Address}

Date Section

Surname first - no titles
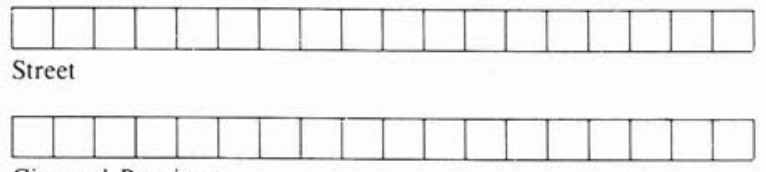

City and Province

Postal Code

\section{Changement d'adresse}

Date Section

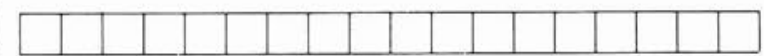

Prénom en avant - pas de titres

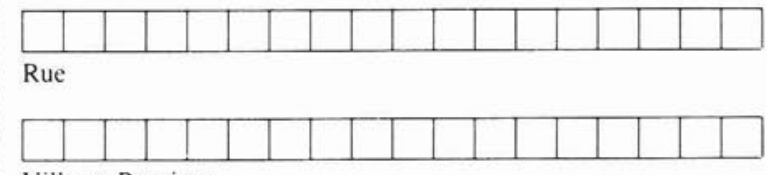

Ville et Province

Code Postale 